\title{
Chapter 1 \\ Introduction: A Critical Appraisal of Major Water Engineering Projects and the Need for Interdisciplinary Approaches
}

\author{
Reinhard F. Hüttl, Oliver Bens, Christine Bismuth, Sebastian Hoechstetter, \\ Hans-Georg Frede, and Hans-Joachim Kümpel
}

\subsection{Ecological Challenges, Social and Economic Opportunities: The Multiple Facets of Major Water Engineering Projects}

Water touches every aspect of human existence on planet earth. While this notion may be regarded as a triviality, it nevertheless has highly complex consequences. Water as a georesource is subject to many pressures due to its multiple functions that go far beyond its role as the fundamental basis of organic life. For instance, antagonistic social, economic and ecological demands meet to form the "waterenergy-food" nexus. Rising population numbers, changing lifestyles and climate change have substantial impacts on water resources and aquatic ecosystems. Furthermore, water is a factor in peace among nations: water can be both a source

R.F. Hüttl $(\bowtie) \bullet$ O. Bens $\bullet$ S. Hoechstetter

Helmholtz Centre Potsdam - GFZ German Research Centre for Geoscience,

Telegrafenberg, 14473 Potsdam, Germany

e-mail: huettl@gfz-potsdam.de

C. Bismuth

Interdisciplinary Research Group Society - Water - Technology,

Berlin-Brandenburg Academy of Sciences and Humanities,

Jägerstraße 22/23, 10117 Berlin, Germany

Helmholtz Centre Potsdam - GFZ German Research Centre for Geosciences,

Telegrafenberg, 14473 Potsdam, Germany

H.-G. Frede

Institute of Landscape Ecology and Resource Management (ILR),

Justus-Liebig-Universität Gießen, Heinrich-Buff-Ring 26-32, 35392 Gießen, Germany

H.-J. Kümpel

Federal Institute for Geosciences and Natural Resources (BGR),

Stilleweg 2, 30655 Hannover, Germany 
of controversy and of cooperation. The "hidden core" of many international conflicts can be regarded as disputes over the access to water.

As a consequence, in many regions of the world, major water engineering projects (MWEPs) such as dams, hydropower plants, large scale irrigation schemes in agriculture, channels for navigation, drinking water transfer connection, etc. are considered as a suitable means for covering the demand for energy and water. In the recent years, rising needs for energy and food have even led to some sort of "renaissance" of MWEPs. New actors - investors, emerging nations and multi-industry companies - have appeared on the scene and economic interests have in many cases impeded a thorough public debate about possible alternatives. The plans for the construction of the Nicaragua Canal as an alternative to the Panama Canal serve as an illustration of such a controversial "megaproject".

Taken all together, MWEPs have significantly shaped societies, economies and ecosystems. This poses crucial questions to scientists in their role as advisors to decision makers: by what means can the future use of water be organised in the most efficient, but also most sustainable way? What are the consequences of further large-scale interventions? And, do the long-term effects of MWEPs limit the number and scope of future options for action and decision-making? Reflecting on these fundamental questions is the main motivation of the book at hand.

\subsection{Interdisciplinary Research on Water Resources}

Looking back, it has often been "technocratic thinking" that has paved the way for MWEPs. Expected influences on ecosystems, societies and economies have been oversimplified or misjudged in the planning stages. Only retrospectively, in many cases, it has turned out that these interventions had taken place within highly complex and coupled systems. The outcome of supposedly simple and determinate water management measures had proven to be unpredictable in advance, with some of the impacts affecting societies decades or even centuries later. The desire for immediate and simple on-hand solutions has a tendency to blur people's vision and rational thinking when it comes to assessing burdens on future generations. The awareness that technical measures alone are not sufficient for meeting present and future challenges in resource management is a relatively young one, and it still needs to be backed up by scientific, ethical, social and political reflections.

This is where the need for interdisciplinary approaches and research designs comes into play. Interdisciplinary research in its true sense is not a goal as such but must be tailored to address many-faceted research questions in their full complexity and to shed a new light on old problems. In this respect, water resource management and the imbalance between mankind's technological capabilities and its systemic intelligence are an ideal field of interdisciplinary research: we deal with coupled and complex systems, we have to find immediate answers concerning the adaptation and mitigation of the effects of climate change, and we have to integrate social, economic and ecological aspects into long-term water management schemes. Undoubtedly, a task such as this would demand too much from the knowledge provided by one single scientific discipline alone. 


\subsection{The Interdisciplinary Research Tradition of the Berlin- Brandenburg Academy of Sciences and Humanities}

The Berlin-Brandenburg Academy of Sciences and Humanities provides an optimal stage for such integrated and interdisciplinary research endeavours. Since 1994, more than 70 Interdisciplinary Research Groups (IRG) have been established there, becoming an out of the ordinary work concept within German research landscape. The general objective of the IRGs is to seize on topics of high scientific and societal relevance, to conduct research on questions of future importance and to initiate a dialogue between science and society. In all of these projects, close relations between members of the Academy and researchers from different national and international research institutions have developed. Another important objective of the Academy is to provide knowledge-based advice for the society and for politics.

In 2011, based on an initiative of Reinhard Hüttl and Oliver Bens, the IRG Society - Water - Technology was established for a term of 3 years. The idea of this IRG, whose members and associates form the group of authors of this book, fits perfectly into this tradition.

\subsection{Aims and Working Structure of the Interdisciplinary Research Group Society - Water - Technology}

The overarching aim of the IRG was to comprehensively describe the framework conditions of major water engineering projects and to analyse their impact on the ecology, economy and society. Based on its analyses and findings, policy recommendations are formulated and research gaps are pointed out. In order to accomplish this, it was necessary to identify those mechanisms that are necessary for the functional continuity of MWEPs - i.e. for their successful and socially acceptable construction - their continuing operation and their adaptation to the targeted conceptual implementation of strategies. The analysis of MWEPs and their impacts and benefits has considered possible future development trends on the basis of present situations and also on the basis of historical reviews. This was accomplished by closely scrutinising two representative case studies: the Fergana Valley in Central Asia and the Lower Jordan Basin in the Middle East.

In the Fergana Valley, the main object of research were the impacts of the construction of a huge irrigation system during the former Soviet period and its effects on present societies and economies as well as on ecosystems along the downstream parts of the big rivers. Thus, the Fergana Valley case study was essential for the development of a common interdisciplinary research methodology and for studying the concept of "path dependencies".

The second case study in the Lower Jordan Basin dealt with the planned Red Sea - Dead Sea Conveyance Project to halt the further decline of the Dead Sea water level resulting from extensive water extraction from the Jordan River. This case 
study allowed the IRG to assess and to evaluate the planning processes of transboundary projects. It provided valuable information on the strengths and weaknesses of international water law as well as on the relations between different riparian states and the prerequisites for successful cooperation.

The IRG was organised according to these case studies in two different subgroups or "clusters". Overarching themes were discussed in the general assembly. The research instruments of the IRG consisted of profound literature research, thematic workshops, study visits to the Fergana Valley and the Lower Jordan Basin, public symposiums and thematic lectures. In addition, two expertise reports on Water Ethics (Armin Grunwald) and on International Water Law (Ute Mager) were conducted within the scope of the research group.

A workshop with an international line-up on The Red Sea - Dead Sea Water Conveyance Project: An opportunity for regional cooperation and improved water management in the Jordan River Basin was held in Potsdam, Germany, in December 2013. Speakers included Stefan Geyer (Helmholtz Centre for Environmental Research UFZ, Halle), Heinz Hötzl (Karlsruhe Institute of Technology KIT, Karlsruhe), Harald Kunstmann (Karlsruhe Institute of Technology KIT, Garmisch-Partenkirchen), Muath Abou Sadah (Palestine Hydrology Group, Ramallah, Palestinian Territories), Elias Salameh (University of Jordan, Amman, Jordan), Uri Shani (Hebrew University of Jerusalem, Israel), Gerhard Smiatek (Karlsruhe Institute of Technology KIT, Garmisch-Partenkirchen), Katja Tielbörger (Tübingen University, GLOWA Jordan River), Yacov Tsur (Hebrew University of Jerusalem, Israel) and Valerie Yorke (NCCR Trade Regulation, World Trade Institute, University of Bern, Switzerland).

The "academy lectures", a unique event format for disseminating research results to the public in layman's terms, have dealt with Water Ethics - Reflections on Handling Resource Conflicts (Armin Grunwald), Major Water Engineering Projects and their Impact on Ecology and Water Cycles - Opportunities and Risks (Axel Meyer and Klement Tockner), The Fergana Valley in Central Asia-Conflicts Regarding the Georesource Water (Hermann Kreutzmann) and The Economic Value of Water Habitats - Approaches and Evaluating Experiences in the Lower Jordan Basin (Nir Becker).

Several members of the research group have furthermore conducted a number of research journeys to the case study areas in the Middle East and in Central Asia. As part of these stays, numerous regional experts from science, administration and nongovernmental organisations were involved in discussions and field trips, allowing for in-depth insights into the specific regional contexts. Findings of these research journeys formed an important basis for the further analyses and eventually paved the way for this volume.

\subsection{Acknowledgements}

The editors of this book and the members of the research group would like to express their gratitude to the following experts from the case study areas, who made a significant contribution to the success of the project: 
Jordan (October 2013): Daniel Busche (Deutsche Gesellschaft für Internationale Zusammenarbeit GIZ, Jordan), Niklas Gassen (Federal Institute for Geosciences and Natural Resources BGR, Hanover), His Excellency Saad Abu Hammour (Ministry of Water \& Irrigation, Jordan Valley Authority, Amman, Jordan), Marwan Al Raggad (University of Jordan, Water and Environment Research and Study Centre, Amman, Jordan), Amer Salman (Faculty of Agriculture, University of Jordan, Amman, Jordan), Ali Subah (Ministry of Water and Irrigation, Amman, Jordan), Manuel Schiffler (KfW Development Bank, Berlin) and Matthias Toll (Federal Institute for Geosciences and Natural Resources BGR, Hanover).

Israel and Palestinian Territories (December 2013): Ruth Arnon (Israel Academy of Sciences and Humanities, IASH), Menahem Yaari (Israel Academy of Sciences and Humanities), Abdelrahman Alamarah (Palestinian Hydrology Group for Water \& Environmental Resources Development, Ramallah), Nir Becker (Department of Economics, Tel-Hai College, Upper Galilee, Israel), Gidon Bromberg (Friends of the Earth Middle East), Rebhy A. El Sheikh (Palestinian Water Authority), Eran Feitelson (Department of Geography, Advanced School for Environmental Studies, The Hebrew University of Jerusalem, Israel), Oded Fixler (Israel Water Authority), Barak Herut (Israel Oceanographic \& Limnological Research, Israel), Ahmad M. Hindi (Palestinian Water Authority, Ramallah), Bob Lapidot (Israel Academy of Sciences and Humanities, IASH), Clive Lipchin (Center for Transboundary Water Management, Arava Institute, Israel), Doron Markel (Monitoring and management Lake Kinneret and its watershed, Water Authority, Israel), Klaus Schelkes (Federal Institute for Geosciences and Natural Resources BGR, Hanover), Abraham Tenne (Desalination Division, Water Authority, Israel) and Menahem Yaari (Israel Academy of Sciences and Humanities, IASH).

Fergana Valley, Uzbekistan (May 2014): Iskandar Abduallaev (The Regional Environmental Centre for Central Asia, CAREC, Almaty, Kazakhstan), Akhmedov Djamaleddin (Water Users Association "Kadyrjon Azamjon", Fergana Valley, Uzbekistan), Victor A. Dukhovny (Scientific Information Center of the Interstate Coordination Water Commission of the Central Asia, SIC ICWC, Tashkent, Uzbekistan), Ahmad Hamidov (Humboldt Universität zu Berlin, Germany), Akmal Karimov (International Water Management Institute, IWMI, Tashkent, Uzbekistan), Shavkat Kenjabaev (Scientific Information Center of the Interstate Coordination Water Commission of the Central Asia, SIC ICWC, Tashkent, Uzbekistan), Alfiya Khaliullina (SIC ICWC), Markus Müller (Deutsche Bank AG, Frankfurt), Maraliev Maraim (Water Users Association "Kadyrjon Azamjon", Fergana Valley, Uzbekistan), Bolot Moldobekov (Central Asian Institute of Applied Geosciences, CAIAG, Bishkek, Kyrgyz Republic), Azim Nazarov (Nazar Business and Technology Limited Consulting NBT, Tashkent, Uzbekistan), Olivier Normand (Regional Rural Water Supply \& Sanitation Project, Fergana City, Uzbekistan, Swiss Agency for Development and Cooperation), Nailja Rezjapova (Friedrich Ebert Foundation, Tashkent, Uzbekistan), Mukhtar Ruziev (SIC ICWC), Vitaliy Stepanov (SIC ICWC), Galina Stulina (Scientific Information Center of the Interstate Coordination Water Commission of the Central Asia, SIC ICWC, Tashkent, Uzbekistan), Elena Tsay (SIC ICWC) and Thierry Umbehr (Swiss Agency for Development and Cooperation, Swiss Cooperation Office Uzbekistan). 
Additional advice was provided by the following external guests and experts: Volker Frobarth (Programme Director "Transboundary Water Management in Central Asia", GIZ), Abror Gafurov (German Research Centre for Geosciences GFZ, Potsdam), Wolfgang Kinzelbach (ETH Zurich), Stefano Parolai (German Research Centre for Geosciences GFZ, Potsdam), Daniela Scheetz (Climate and Environmental Foreign Policy, Sustainable Economy, Federal Foreign Office, Berlin), Joop de Schutter (UNESCO-IHE, Institute for Water Education, Delft), Jenniver Sehring (Deutsche Gesellschaft für Internationale Zusammenarbeit, GIZ), Hinrich Thölken (Climate and Environmental Foreign Policy, Sustainable Economy, Federal Foreign Office, Berlin), Katy Unger-Shayesteh (German Research Centre for Geosciences GFZ, Potsdam), Thomas Vetter (Climate and Environmental Foreign Policy, Sustainable Economy, Federal Foreign Office, Berlin) and Michael Weber (German Research Centre for Geosciences GFZ, Potsdam).

The scientific and administrative management of the Berlin-Brandenburg Academy of Sciences and Humanities gave its utmost support to the project. The research group particularly owes great thanks to Wolf-Hagen Krauth, Regina Reimann, Andreas Schmidt, Ute Tintemann and Janina Amendt.

For the final preparation of the manuscript of this book and for invaluable organisational and administrative support, special thank goes to Anna Kaiser, Yvonne Dinter and Edward Ott. We would also like to thank Dietmar Kraft, who shouldered the scientific coordination tasks in the early phase of the project.

For the thorough editing and proof-reading of the manuscript, the group thanks Ian Whalley and for the technical review of the contributions, Iskandar Abdullaev (CAREC, Regional Environmental Centre for Central Asia, Almaty), Ines Dombrowsky (DIE, German Development Institute, Bonn), Uwe Grünewald (Brandenburg University of Technology Cottbus-Senftenberg) and Yoav Kislev (Hebrew University of Jerusalem).

For the support in the organisation of the research trip to the Fergana Valley, we owe particular thanks to the team of the Scientific Information Center of Interstate Coordination Water Commission (SIC ICWC), especially to Victor Dukhovny, Galina Stulina and Shavkat M. Kenjabaev (SIC ICWC/SANIIRI).

Over and above the basic funding of the project by the Berlin-Brandenburg Academy of Sciences and Humanities, the activities of the working group were supported by various institutions. We are especially grateful to the German Academic Exchange Service (DAAD), the Hermann und Elise geborene Heckmann Wentzel Foundation and the National Academy of Science and Engineering (acatech), the Swiss Academy of Engineering Sciences (SATW), the Israel Academy of Sciences and Humanities (IASH) and the Austrian Academy of Sciences (ÖAW). 


\subsection{Members of the Interdisciplinary Research Group Society - Water - Technology}

Members of the research group were: Oliver Bens (German Research Centre for Geosciences GFZ, Potsdam), Petra Dobner (Martin-Luther-Universität HalleWittenberg), Rolf Emmermann (German Research Centre for Geosciences GFZ, Potsdam), Hans-Georg Frede (Justus-Liebig-Universität Gießen), Manuel Frondel (Rheinisch-Westfälisches Institut für Wirtschaftsforschung RWI, Essen), Carl Friedrich Gethmann (Universität Siegen), Gerhard Glatzel (Universität für Bodenkultur, BOKU, Vienna), Hermann H. Hahn (Heidelberg Academy of Sciences and Humanities, HAW), Bernd Hansjürgens (Helmholtz Centre for Environmental Research UFZ, Leipzig), Bernd Hillemeier (Technische Universität Berlin), Reinhard Hüttl (spokesperson of the IRG, German Research Centre for Geosciences GFZ, Potsdam), Hermann Kreutzmann (Freie Universität Berlin), Hans-Joachim Kümpel (Federal Institute for Geosciences and Natural Resources BGR, Hanover), Axel Meyer (Konstanz University), Timothy Moss (Leibniz Institute for Regional Development and Structural Planning IRS, Erkner), Helmar Schubert (Karlsruhe Institute of Technology KIT, Karlsruhe), Herbert Sukopp (Technische Universität Berlin), Klement Tockner (Leibniz Institute of Freshwater Ecology and Inland Fisheries IGB, Berlin), Menahem E. Yaari (Israel Academy of Sciences and Humanities) and Ugur Yaramanci (Leibniz Institute for Applied Geophysics LIAG, Hanover). The group was supported by the scientific and administrative coordination team consisting of Christine Bismuth, Yvonne Dinter, Sebastian Hoechstetter, Anna Kaiser and Dietmar Kraft.

Berlin, in April 2015

The editors of this volume and the speakers of the clusters Fergana Valley and Lower Jordan Valley

Open Access This chapter is distributed under the terms of the Creative Commons Attribution Noncommercial License, which permits any noncommercial use, distribution, and reproduction in any medium, provided the original author(s) and source are credited. 